\title{
HISTOLOGICAL STRUCTURE OF THE SKIN \\ OF ARCTIC CHARR, SALVELINUS ALPINUS (L.) FROM SPITSBERGEN
}

\section{Andrzej WITKOWSKI ${ }^{1 *}$, Katarzyna KALETA ${ }^{2}$, Jan KURYSZKO ${ }^{2}$, Jan KUSZNIERZ ${ }^{3}$}

\author{
${ }^{1}$ Museum of Natural History, Wrocław University, Wrocław, Poland \\ ${ }^{2}$ Division of Histology and Embryology, Agricultural University of Wroctaw, Poland \\ ${ }^{3}$ Zoological Institute, Wrocław University, Wrocław, Poland
}

Witkowski A., Kaleta K., Kuryszko J., Kusznierz J., 2004. Histological structure of the skin of Arctic charr, Salvelinus alpinus (L.) from Spitsbergen. Acta Ichthyol. Piscat. 34 (3): 241-251.

Background. Like in most salmonids, females of Artic charr dig nests, while spawning, to deposit their eggs, while the role of males is most often limited to the territorial defence. The aim of this study was to examine the histological structure of skin in both sexes, in the body parts which are particularly exposed to mechanical damage during spawning.

Material and methods. Based on material representing three forms (anadromous, landlocked (lake), and dwarf/riverine), collected in the pre-spawning and spawning periods, histological structure of the skin was analysed for three body areas: dorsum (back), side, and venter (belly).

Results. In females of all the forms the skin in analysed body areas was thicker and contained more mucous cells, compared to males. In the ventral region it was the thickest, on the dorsum - the thinnest. A comparison of the skin structure in the three forms showed that, in the land-locked form (both sexes), the skin in all the body parts was thicker and richer in mucous cells, compared to the anadromous form.

Conclusion. The skin of Arctic charr females plays a protective role, preventing mechanical damage during nest digging and egg burying, because of its substantial thickness and the abundance of mucous cells especially in the ventral region.

Key words: fish, salmonids, Arctic charr, lithophiles, nest digging, skin.

\footnotetext{
* Correspondence: Prof. dr hab. Andrzej Witkowski, Muzeum Przyrodnicze, Uniwersytet Wrocławski, ul. Sienkiewicza 21, 50-335 Wrocław, Poland, e-mail: a.witkowski@biol.uni.wroc.pl
} 


\section{INTRODUCTION}

The Arctic charr, Salvelinus alpinus L. has a circumpolar distribution, occurring commonly in the northernmost areas of North America, Europe, and Asia, and islands of the Arctic Ocean (e.g. Baffin Land, Greenland, Iceland, Jan Mayen, the Svalbard Archipelago, the Shetland-, Orkney-, Faroe Islands, the British Isles and the Novaya Zemlya Islands). In some areas it is the only fish species. It was also recorded from continental Europe (Alpine lakes and also Lakes Onega and Ladoga) and North America, occurring in isolated areas and in lake localities (Johnson 1980). If charr from the Alpine area and charr from Scandinavia are considered the same species, the name Salvelinus umbla (L.) has nomenclatural priority over the name Salvelinus alpinus L. and should be used as the correct and valid name for this fish species. If, however, charr from the Alpine area and charr from Scandinavia are considered to be two distinct species (Kottelat 1997), then the Alpine species is $S$. umbla and the Scandinavian one is $S$. alpinus.

Within its distribution range the Arctic charr, an extremely adaptable species, occurs as numerous (often sympatric) forms of ecotype character i.e. anadromous, land-locked, and dwarf/riverine (Balon 1980). Also in a few regions of southern Spitsbergen (Svalbard Archipelago) three sympatric forms of this species have been distinguished (Gullestad 1975, Hansen and Overrein 2000, Winnicki 1993); they spawn either in rivers or in lakes.

Considering the fact that the forms differ in the size attained, body proportions and coloration, as well as in the life cycle (Radziun 1993), it is essential to examine also the structure of their skin in the spawning season, which reflects their life in different environmental conditions and should display adaptations to lithophilous spawning (Balon 1975).

\section{MATERIAL AND METHODS}

Material for the present study was collected in the region of the Hornsund Fjord in 2003 during the 16th scientific expedition from the Wrocław University to Spitsbergen. The Arctic charr were sampled from the same bodies of water, which have been studied a decade ago by Radziun (1993).

The fish were caught within 8-12 August 2003, just before the spawning season of the species, in the Revelva River (anadromous and dwarf/riverine form) and Lake Svartvatnet (land-locked form). According to Hansen and Overrein (2000) and Dr P. Głowacki (pers. comm.), the Arctic charr occurring in south-western Spitsbergen, spawns from August trough early September. Six individuals, two of each form (a male and a female), were selected for histological examination.

The measurements (TL) of the fish examined were the following: 1/ anadromous form (Revelva River): male, $547 \mathrm{~mm}$; female, $507 \mathrm{~mm}$; 2/ dwarf/riverine form (Revelva R.): male, $231 \mathrm{~mm}$; female, $180 \mathrm{~mm}$; 3/ land-locked form (Svartvatnet Lake): male, $533 \mathrm{~mm}$; female, $496 \mathrm{~mm}$. 
From each fish, skin fragments were sampled (ca. $8 \times 8 \mathrm{~mm}$ ) from three body parts (dorsal—just below fin D, lateral —at the level of lateral line, and ventral-between fins $\mathrm{V}$ and $\mathrm{A}$ ) to be subsequently preserved for 48 hours in a 4.0-\% formalin solution, then dehydrated and embedded in paraffin. Serial sections, 5-7 $\mu \mathrm{m}$ thick, were stained with haematoxylin and eosin according to Delafield, with Alcian Blue staining method.

In addition, a histometrical study was performed on the epidermis, taking into consideration its thickness and the number of mucous cells. The epidermis thickness was measured using a cylinder ocular micrometer; the number of mucous cells counted within $1 \mathrm{~mm}^{2}$. In both cases 10 measurements and counts for sections from each body part were made. The results are shown in Tables 1 and 2. Student t-test was used to estimate the significance of differences, $P>0.05$ being assumed as statistically significant. Calculations were done with Statistica PC.

Table 1

Thickness of the epidermis $[\mu \mathrm{m}]$ of $S$. alpinus from Spitsbergen $(\bar{x} \pm s)$

\begin{tabular}{cccc}
\hline & \multicolumn{3}{c}{ Body area } \\
\cline { 2 - 4 } & Form & Side & Dorsum \\
\hline $\begin{array}{c}\text { Land-locked form } \\
\text { Female }\end{array}$ & $192.09 \pm 7.26^{*}$ & $174.28 \pm 6.31^{*}$ & $164.92 \pm 5.96^{*}$ \\
Male & $168.26 \pm 5.97^{*}$ & $151.91 \pm 6.12^{*}$ & $138.16 \pm 5.84^{*}$ \\
Dwarf/riverine form & & $179.16 \pm 5.87$ & $158.19 \pm 5.84^{*}$ \\
Female & $186.19 \pm 6.94^{*}$ & $142.28 \pm 5.61^{*}$ & $124.51 \pm 4.94^{*}$ \\
Male & $159.02 \pm 6.94^{*}$ & & $131.36 \pm 4.12^{*}$ \\
Anadromous form & $154.18 \pm 5.86^{*}$ & $161.14 \pm 5.71$ & $126.21 \pm 3.94^{*}$ \\
Female & $158.91 \pm 5.49^{*}$ & $149.81 \pm 4.67$ & \\
Male & & & \\
\hline
\end{tabular}

* significant at $P>0.05$.

\section{RESULTS}

General skin structure in S. alpinus

A characteristic feature of all ecological forms of Arctic charr and each body part analysed, is the palisade arrangement of cells constituting the basal layer, which is in fact the generative layer of the epidermis. Above the basal layer there are polygonal cells within which keratosis symptoms are observed. Among the polygonal cells there are mucous cells, representing epithelial mucous glands, which vary in the amount of mucous substances and in the intensity of their synthesis. Having their cytoplasm filled with mucous substances and the nucleus pressed against the cell membrane, they are clearly different from the polygonal cells. The epithelium surface is covered by flat exfoliated cells. Just beneath the basal membrane there are melanophores of varied pigment concentration. The connective tissue, which composes the skin proper, comprises numerous fibroblasts, fibrocytes, and undifferentiated mesenchymal cells. 
The morphotic part of intercellular space contains fibres of connective tissue, in which collagen and reticular fibres predominate. In the zone of the skin proper connective tissue (particularly in the part above the epithelium), numerous capillary blood vessels occur.

The skin microscopic structure presented above for S. alpinus from Spitsbergen is similar to that described earlier by Pickering (1974).

Table 2

Number of mucous cells on the surface of $1 \mathrm{~mm}^{2}$ of epidermis in S. alpinus from Spitsbergen $(\bar{x} \pm s)$

\begin{tabular}{lccc}
\hline \multirow{2}{*}{ Form } & \multicolumn{3}{c}{ Body area } \\
\cline { 2 - 4 } & \multicolumn{1}{c}{ Venter } & Side & Dorsum \\
\hline $\begin{array}{l}\text { Land-locked form } \\
\text { Female }\end{array}$ & $68.25 \pm 5.31^{*}$ & $54.71 \pm 3.96^{*}$ & $41.08 \pm 3.62^{*}$ \\
Male & $51.34 \pm 4.67^{*}$ & $45.82 \pm 4.11$ & $34.21 \pm 3.06^{*}$ \\
Dwarf/riverine form & & & \\
Female & $74.19 \pm 5.54^{*}$ & $61.29 \pm 4.82^{*}$ & $49.98 \pm 3.53^{*}$ \\
Male & $54.24 \pm 3.17^{*}$ & $41.39 \pm 3.45$ & $38.89 \pm 3.53^{*}$ \\
Anadromous form & & & \\
Female & $47.54 \pm 3.09^{*}$ & $40.99 \pm 3.46$ & $36.24 \pm 4.39^{*}$ \\
Male & $43.19 \pm 4.24^{*}$ & $40.81 \pm 4.53$ & $31.69 \pm 3.94^{*}$ \\
\hline
\end{tabular}

* significant at $P>0.05$.

Land-locked form

It is characteristic of females to have very abundant mucous cells, particularly in the skin of ventral and lateral sections. These cells become fewer dorsally. Ventrally and laterally the mucous cells are at different stages of mucus production and discharge. In the zone where the cells discharge their mucus, the flat corneous cells forming the epithelium become sparser. Melanophores are the most numerous dorsally and laterally, whereas in the skin of the ventral part they are single and occur sporadically (Figs. 1-4).

Figs. 1-7. Salvelinus alpinus, from Spitsbergen; land-locked form. Fig. 1. Female, ventral epidermis; numerous mucous cells (arrow) occupy most of the epithelium; H + E. Fig. 2. Female, lateral epidermis; poorer developed mucous cells (arrow) and forming epithelial cells of the superficial layer (n); H + E. Fig. 3. Female, dorsal epidermis; zone of mucous cells disappearing; superficial layer exfoliated (a); H + E. Fig. 4. Female, ventral epidermis. Numerous mucous cells; Alcian Blue. Fig. 5. Male, ventral epidermis; fewer mucous cells (arrow); H + E. Fig. 6. Male, lateral epidermis; clear decrease in the number of mucous cells; proliferating cells of the germinal layer (r); Few melanophores in the skin proper (arrow); H + E. Fig. 7. Male, dorsal epidermis; few mucous cells; proliferation of the basal layer of epidermis (r); superficial layer exfoliated (a); melanophores in the skin proper (arrow); $\mathrm{H}+\mathrm{E}$; scale bars $=100 \mu \mathrm{m}$ 


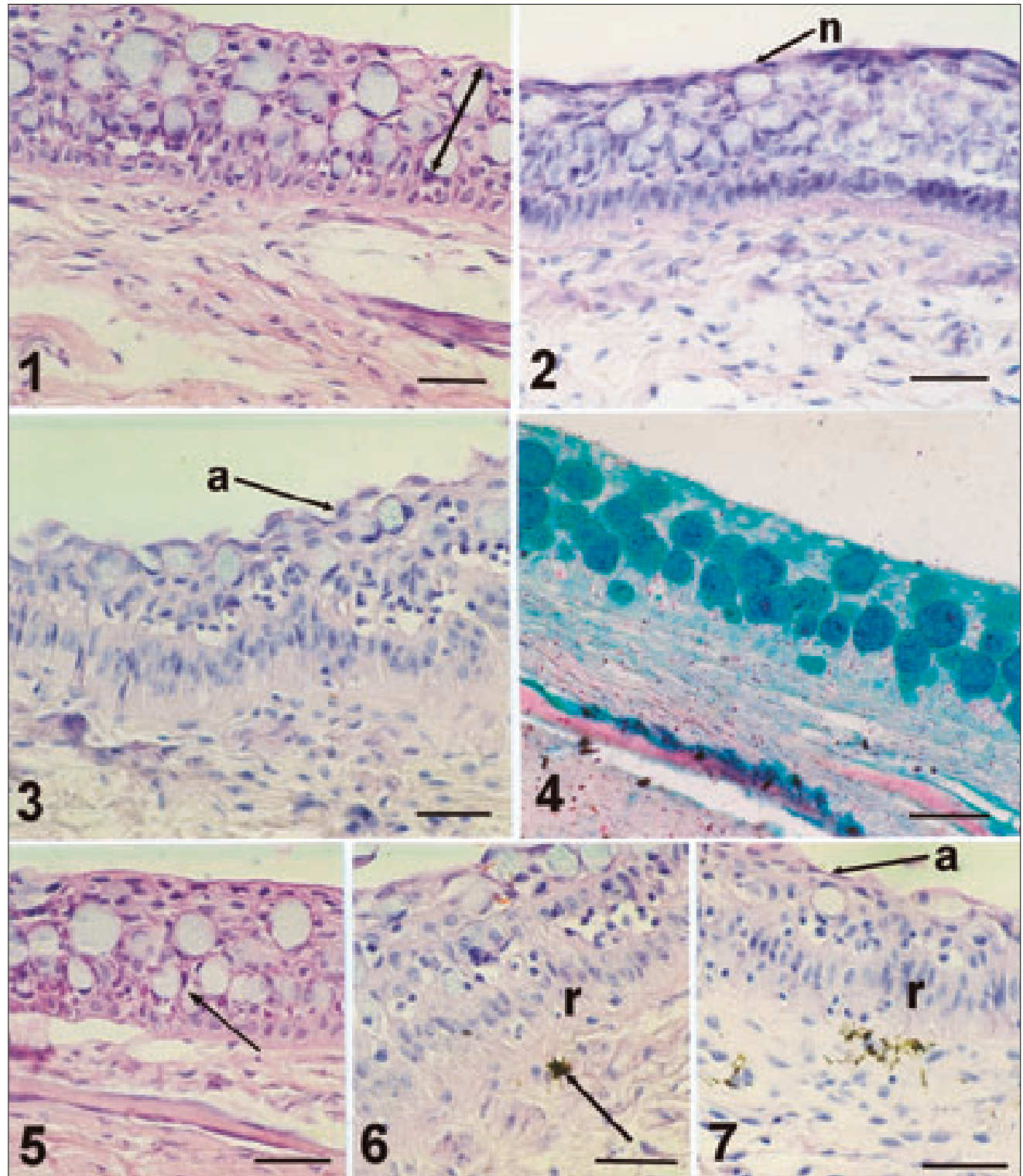

Figure captions on facing page 


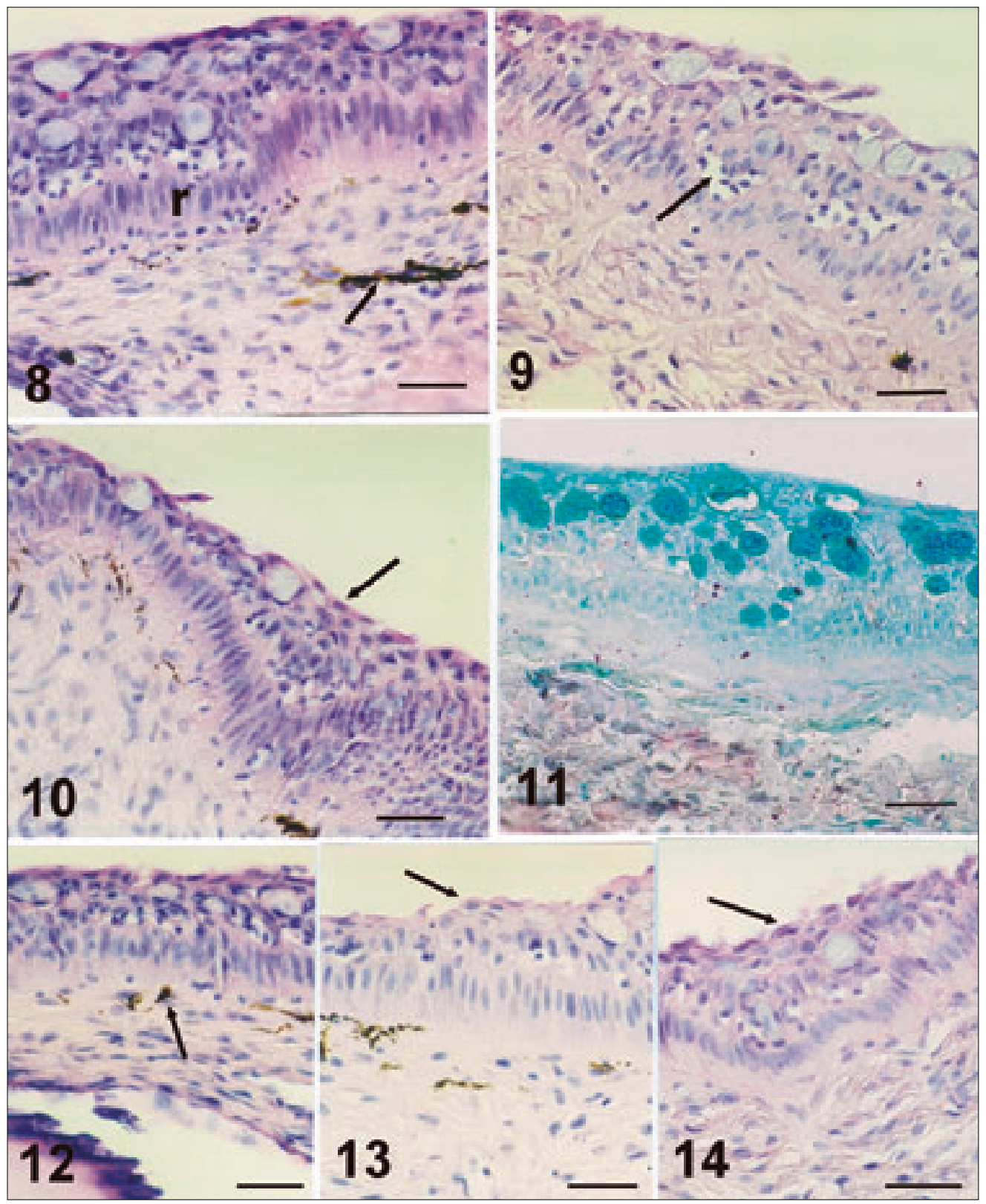

Figure captions on facing page 
In males the number of mucous cells in all analysed body sections is clearly smaller than in females. On the other hand, the concentration of melanophores in the skin of the dorsum and sides is considerably higher (Figs. 5-7).

Dwarf/riverine form

In females, high abundance of mucous cells is observed ventrally and laterally. The cells are numerous and filled with mucus. Some of them are swollen. In their vicinity, polygonal cells are observed. In the basal layer, many areas of mitotic divisions are noted. Beneath the basal membrane of the epithelium few melanophores are situated. In the dorsal skin, the melanophores are very abundant, sometimes forming a continuous layer; few mucous cells occur.

In the case of males the histological picture of the skin is similar to that of the landlocked form, but the number of melanophores is considerably higher both dorsally and laterally.

Anadromous form

Females are characterized by very numerous mucous cells in the skin of the ventral and lateral sections; areas of discharged mucous cells predominating. In the basal zone of the epithelium numerous mitotic divisions are observed which is an expression of epidermis renewal and regeneration. At the sites of discharged mucous cells new ones appear. The dorsal skin abounds in melanophores (Figs. 8-11).

The histological picture of the male skin resembles that found in the land-lockedand dwarf/riverine forms (Figs. 12-14).

An analysis of the epithelium thickness in the three body regions of all forms of the Arctic charr has revealed that that layer is the thickest in the land-locked form and the thinnest in the anadromous one. In both sexes, during the spawning season the

Figs. 8-14. Salvelinus alpinus from Spitsbergen; anadromous form. Fig. 8. Female, ventral epidermis; fewer mucous cells compared to the land-locked form; numerous mitotic divisions in the proliferation zone of the skin (r); melanophores in the skin proper (arrow); H + E. Fig. 9. Female, lateral epidermis; well-developed mucous cells in various functional stages; next generations of mucous cells forming in place of discharged cells (arrow); $\mathrm{H}+$ E. Fig. 10. Female, dorsal epidermis; few mucous cells, decreased premucogenic zone; melanophores in the skin proper (arrow); H + E. Fig. 11. Female, ventral epidermis; single mucous cells; Alcian Blue. Fig. 12. Male, ventral epidermis; clearly reduced number of mucous cells; decreased premucogenic zone; melanophores in the skin proper (arrow); H + E. Fig. 13. Male, lateral epidermis; clear decrease in the number of mucous cells; cells of superficial layer fill spaces remaining after mucous cells (arrow); $\mathrm{H}+\mathrm{E}$. Fig. 14. Male, dorsal epidermis; superficial layer of epidermis fully exfoliated (arrow); single mucous cells; $\mathrm{H}+\mathrm{E}$; scale bars $=100 \mu \mathrm{m}$ 
thickest epithelium occurs in the ventral part of the skin. Starting from this region, it becomes thinner towards the back. There are also distinct differences between the sexes: it is typical of females to have a clearly thicker skin compared to males. Moreover, the number of mucous cells in all body sections analysed is clearly higher in females.

Statistically significant differences were found in the epithelium thickness between the three analysed body areas in males. The anadromous form is an exception in the fact that only the difference between the ventral and dorsal areas is significant. In females, statistically significant differences between the three body regions were found only in the land-locked form. In the dwarf/riverine and anadromous forms, statistically significant differences were observed only between the ventral and dorsal areas (Table 1).

Histometrical analysis of the number of mucous cells revealed statistically significant differences:

$1 /$ in females of the land-locked and dwarf/riverine forms between the three body areas, (in the anadromous form such differences involved only the ventral- and dorsal area); $2 /$ in males of all three forms, statistically significant differences pertained mainly to the dorsal and ventral areas (Table 2).

\section{DISCUSSION}

Many fish species just before and during spawning assume nuptial coat manifested as change of colour and shape (Jobling 1995). Often, especially in cyprinid fishes, breeding tubercles appear which, during spawning, play an important role, mainly keeping and increasing contact between individuals of different sexes during the spawning act; protecting body from damage during nest construction. The breeding tubercles on the ventral side of female body may protect the anus and urogenital papillae against mechanical damage during inserting them between stones and gravel in order to lay eggs (Fabricius and Gustafson 1955, Collette 1965, 1977, Wiley and Collette 1970, Witkowski 1982, Witkowski and Rogowska 1991).

Salmonid fishes during spawning have no visible breeding tubercles (Collette 1977), though Vladykov $(1954,1970)$ noted their presence in a single species-lake trout, "Cristivomer namaycush" (valid name Salvelinus namaycush (Walbaum, 1792)). Stoklosova $(1966,1970)$ and Menzies (1931) found that in males of sea trout, Salmo trutta trutta L. and Atlantic salmon, Salmo salar L. the skin during spawning was rougher and thicker than in females. The female skin was found to contain clearly more mucous cells. Their secretion in species of the genus Oncorhynchus clearly increases during spawning migrations (van Oosten 1957). According to the abovementioned authors, the thickened skin of salmonids in some body areas plays a similar role to that played by tuberculation in other fish taxa. Generally, sexual dimorphism in this group is manifested, apart from other characters, as thicker skin in males (Robertson and Wexler 1969, Hay et al. 1976, Noakes 1980). 
The studied populations of $S$. alpinus from Spitsbergen displayed significant differences in the skin thickness, and especially in the number of mucous cells, between males and females. Noakes (1980) found no clear regularities in this species. He examined three populations of S. alpinus and found that in one (Floods Pond, Maine, USA) the male epidermis was distinctly thicker, in another (Batsvatn Lake, northern Norway) it was possibly thicker, while in the third one (Dösener Lake, Austrian Alps) there were apparently no differences between the sexes. It should be noted that the fish he examined were small (105-324 mm TL) compared to the Spitsbergen individuals (180-547 mm TL).

Like in other salmonids (Scott and Crossman 1973, Bartel 2000a, b), females of Arctic charr dig a nest in the bottom, removing gravel and stones with their caudal fin and lower part of their belly, and then they bury the eggs (Fabricius 1953, Fabricius and Gustafson 1954). In other salmonids, e.g. huchen, Hucho hucho (L.), the excavating female may remove up to about 1.2 tonnes of material (Holčik et al. 1988). Thus these body parts in females are the most exposed to mechanical injury. It seems logical that the female skin in these body regions in salmonids should be thicker and richer in mucous cells, since according to Richards and Pickering (1978), it also prevents infection with Saprolegnia fungus. In the examined males of S. alpinus the skin in all the studied body areas was thinner and contained clearly fewer mucous cells. This may result from the fact that the males only defend their territories/nests and spray their sperm over the laid eggs with no close contact with the rough bottom (Fabricius 1953, Noakes 1980).

The observed clear differences in the skin thickness and number of mucous cells between the three forms of $S$. alpinus from Spitsbergen, in favour of the land-locked form, may result from different conditions in the habitats where they live (sea, lake, river) just before spawning (Gullestad 1975, Johnson 1980, Radziun 1993). This was confirmed by observations of Behnke (1972), after Noakes (1980): "the question of possible population differences is of particular interest, given the polytypic nature of this species, and the known variations from a number of different localities".

\section{ACKNOWLEDGMENTS}

A generous research grant of Prof. dr hab. Zdzisław Latajka, the Rector of the Wrocław University - to support the scientific expedition to Spitsbergen —enabled the collection of the material presently used.

We would like to express our thanks to Dr Beata M. Pokryszko for linguistic improvement of the first draft of the manuscript. 


\section{REFERENCES}

Balon E.K., 1975. Reproductive guilds of fishes: a proposal and definition. Journal of the Fisheries Research Board of Canada 32: 821-864.

Balon E.K., (ed.) 1980. Charrs—-salmonid fishes of the genus Salvelinus. Dr W. Junk bv Publishers, the Hague.

Bartel R., 2000a. Łosoś - Salmo salar Linnaeus, 1758. [Atlantic salmon, Salmo salar Linnaeus, 1758.] pp. 408-415. In: Brylińska M., (ed.) Ryby słodkowodne Polski. [The freshwater fishes of Poland.] Wydawnictwo Naukowe PWN, Warszawa. [In Polish.]

Bartel R., 2000b. Troć morska wędrowna - Salmo trutta m. trutta Linnaeus, 1758. [Sea trout, Salmo trutta m. trutta Linnaeus, 1758.] pp. 415-420. In: Brylińska M., (ed.) Ryby słodkowodne Polski. [The freshwater fishes of Poland.] Wydawnictwo Naukowe PWN, Warszawa. [In Polish.]

Behnke R.J., 1972. The systematics of salmonid fishes in recently glaciated lakes. Journal of the Fisheries Research Board of Canada 29: 639-671.

Collette B.B., 1965. Systematic significance of breeding tubercles in fishes of the family Percidae. Proceedings of the United States National Museum 117: 567-614.

Collette B.B., 1977. Epidermal breeding tubercles and bony contact organs in fishes. pp. 225-268. In: Spearman R.I.C., (ed.) Comparative biology of skin. Symposium of the Zoological Society. Academic Press, London.

Fabricius E., 1953. Aquarium observations on the spawning behaviour of the char, Salmo alpinus. Report of the Institute of Freshwater Research, Drottningholm 31: 14-48.

Fabricius E., Gustafson K.J., 1954. Further aquarium observations on the spawning behaviour of the char, Salmo alpinus L. Report of the Institute of Freshwater Research, Drottningholm 35: 58-104.

Fabricius E., Gustafson K.J., 1955. Observations on the spawning behaviour of the grayling, Thymallus thymallus (L.). Report of the Institute of Freshwater Research, Drottningholm 36: $75-103$.

Gullestad N., 1975. On the biology of char (Salmo alpinus L.) in Svalbard. 1. Migratory and non migratory char in Revvatnet, Spitsbergen. Norsk Polaristitutt Arbok 1973 pp. 125-140.

Hansen J.R., Overrein O., 2000. Røye på Svalbard og Jan Mayen. [Arctic charr from Svalbard and Jan Mayen.] Norsk Polaristitutt Rapportserie 114: 1-42. (In Norwegian.)

Hay J.B., Hodings M B., Roberts R.J., 1976. Androgen metabolism in skin and skeletal muscle of the rainbow trout (Salmo gairdneri) and in accessory sexual organs of the spur dogfish (Squalus acanthias). General and Comparative Endocrinology 29: 402-413.

Holčik J., Hensel K., Nieslanik J., Skacel L., 1988. The Eurasian huchen, Hucho hucho: largest salmon of the world. Dr W. Junk Publishers, Dordrecht, Boston, Lancaster.

Jobling M., 1995. Environmental biology of fishes. Chapman \& Hall Publishers, London.

Johnson L., 1980. The Arctic charr, Salvelinus alpinus. pp. 5-98. In: Balon E.K., (ed.) Charrs-salmonid fishes of the genus Salvelinus. Dr W. Junk bv Publishers, the Hague.

Kottelat M., 1997. An heuristic checklist of the freshwater fishes of Europe (exclusive of former USSR) with an introduction for non-systematists and comments on nomenclature and conservation. Biologia (Bratislava) 52 (suppl. 5): 1-271.

Menzies W.J.M., 1931. The salmon. Its life story. Blackwood and Sons Ltd, Edinburgh and London. 
Noakes D.L.G., 1980. Some histological observations on the skin of charrs. pp. 423-433. In: Balon E.K., (ed.) Charrs—salmonid fishes of the genus Salvelinus. Dr W. Junk bv Publishers, the Hague.

van Oosten J., 1957. The skin and scales. pp. 207-244. In: Brown M.E., (ed.) Physiology of fishes. Academic Press, New York.

Pickering A.D., 1974. The distribution of mucous cells in the epidermis of the brown trout Salmo trutta (L.) and the char Salvelinus alpinus (L.). Journal of Fish Biology 6: 111-118.

Radziun K., 1993. Observations on the Arctic charr, Salvelinus alpinus (L., 1758) from the Hornsund region (Vest Spitsbergen) in 1985-1987. Acta Ichthyologica et Piscatoria 23 (suppl.): 7-21.

Richards R.H., Pickering A.D., 1978. Frequency and distribution patterns of Saprolegnia infection on the mucous cells of the epidermis of the charr Salvelinus alpinus (L.). Journal of Fish Biology 10: 505-512.

Robertson OH., Wexler B.C., 1969. Histological changes in the organs and tissue of migrating and spawning Pacific salmon (genus Oncorhynchus). Endocrinology 66: 229-239.

Scott W.B., Crossman E.J., 1973. Freshwater fishes of Canada. Fisheries Research Board of Canada, Ottawa.

Stoklosova S., 1966. Sexual dimorphism in the skin of sea trout, Salmo trutta. Copeia 1966: 613-614.

Stoklosova S., 1970. Further observations on the sexual dimorphism in the skin of Salmo trutta trutta in relation to sexual maturity. Copeia 1970: 332-339.

Vladykov V.D., 1954. Taxonomic characters of eastern North American chars (Salvelinus and Cristivomer). Journal of the Fisheries Research Board of Canada 11: 904-932.

Vladykov V.D., 1970. Pearl tubercles and certain cranial peculiarities useful in taxonomy of coregonid genera. pp. 167-193. In: Lindsey C.C., Woods C.S., (eds.) Biology of coregonid fishes. University of Manitoba Press, Winnipeg.

Wiley M.L., Collette B.B., 1970. Breeding tubercles and contact organs in fishes: Their occurrence, structure, and significance. Bulletin of the American Museum Natural History 143: $143-216$.

Winnicki A., 1993 . Some observations on biological peculiarities of the Svalbard form of the Arctic charr (Salvelinus alpinus (L.)). Acta Ichthyologica et Piscatoria 23 (suppl.): 3-6.

Witkowski A., 1982. Występowanie, rozmieszczenie i budowa wysypki tarłowej u lipienia europejskiego Thymallus thymallus (L.). [Occurrence, distribution, and structure of breeding tubercles in the European grayling, Thymallus thymallus (L.).] Przegląd Zoologiczny 26: 425-429. (In Polish.)

Witkowski A., Rogowska M., 1991. Breeding tubercles in some European cyprinid fishes (Osteichthyes, Cypriniformes: Cyprinidae). Zoologische Abhandlungen des Staatlichen Museums für Tierkunde, Dresden 46: 131-156.

Received: 22 September 2004

Accepted: 22 December 2004 